\title{
A framework for the formulation of security issues in the field of e-learning using Meta- Synthesis method
}

\author{
Abouzar Arabsorkhi ${ }^{a^{*}}$, Afshin Khodabandeh ${ }^{\text {a }}$ and Laleh Tashakori ${ }^{\text {b }}$
}

${ }^{a}$ Iran Telecommunication Research Center(ITRC), Tehran, Iran

${ }^{b}$ Department of Engineering, Mehriz Branch, Islamic Azad University, Mehriz, Iran

\section{H R O N I C L E}

Article history:

Received January 20, 2014

Accepted 30 August 2014

Available online

August 312014

E-learning

Security issues

Formulating requirements

\section{Introduction}

Development and diffusion of information and communication technology (ICT) has altered activates of social units, business units even influence on governments in the social, economic, political and technological infrastructures. Therefore, a new society has been created called information society (Ziemba \& Olszak, 2012). The major characteristic of these communities is importance of information, knowledge and their resources that needs to protect (Arabsorkhi et al., 2009). Inclusive ICT infrastructure in the information society provides basic admission and facilities for developing variety of electronic functional spaces and supply value added services to all users (Younis et al., 2013). However, the nature of this infrastructure provides a context to operate new type of threats and attacks on security systems, applications or users of e-services (Adams \& Blandford, 2003; Cardenas \& Sanchez, 2005; Defta, 2011). Hence, security concerns are key issues to safe using of these services (Eibl, 2009; Hayaati, 2010).

*Corresponding author

E-mail addresses: abouzar_arab@itrc.ac.ir (A. Arabsorkhi)

C 2014 Growing Science Ltd. All rights reserved. doi: $10.5267 /$ j.ms 1.2014 .8 .037 
The developers and suppliers of technologies are worried data confidentiality increasing e-learning services value and investments volume (Furnell, 1999). Because, inattention to security issues can affect using e-learning services (Adams \& Blandford, 2003; Eibl, 2009; Hayaati, 2010). Nevertheless, there is no merit attention to security issues in practical and theoretical realms (Ramim \& Levy, 2006). This fact shows the importance of doing research in the field of e-learning security. There are some risks and threats in spite of various solutions in the field of e-learning (Eibl, 2008; Cardenas \& Sanchez, 2005; Hitchings, 1995). Some researchers believe that this problem is a result of nonsystematic factors, such as human (Arabsorkhi \& Yadegari, 2010). However, it can argue that inattention to aspects of the developing process; supply management and e-learning services can lead to create risks and attacks in this field (Zuev, 2013). There are two basic requirements to fulfill the security requirements of the technology space, services and preservation in the field of e-learning: First, facing with systematic security threats and challenges of this field (Arabsorkhi \& Yadegari, 2010; Hayaati, 2010) and second, having a comprehensive approach to identify and cover all areas of challenges in the security issues. These two needs can be accountable by providing security framework in the field of e-learning (Mellado et al., 2010).

This paper develops at supporting security requirements in the field of e-learning. The structure of this paper after introduction is as follows. The objectives and literature review of the study are presented in section two. In the third part, research methodology is presented. All stages of metasynthesis method and finding research are expressed in fourth section. The findings are presented by providing conceptual model and finally in section five, conclusions of this study are presented.

\section{Literature review}

There are variety issues in the field of e-learning, which have been investigated in other researches in the conceptual, technical and management sphere. Some of highlighted researches in this field are presented in the Table 1.

Table 1

Summary of literature review

\begin{tabular}{|c|c|c|c|c|c|}
\hline \multirow{2}{*}{ Subject } & \multicolumn{2}{|c|}{ Basic information } & \multirow{2}{*}{$\begin{array}{l}\text { Type of security } \\
\text { issues }\end{array}$} & \multirow{2}{*}{$\begin{array}{l}\text { Formulation/classification } \\
\text { issues }\end{array}$} & \multirow{2}{*}{ Point of issues } \\
\hline & Author/Authors & Year & & & \\
\hline E-learning solutions and security requirements & Arabsorkhi et al. & 2009 & $\begin{array}{l}\text { Standard security } \\
\text { requirement }\end{array}$ & $\begin{array}{l}\text { Managerial, technical and } \\
\text { procedural }\end{array}$ & Focus on Services \\
\hline $\begin{array}{l}\text { Identification and analysis of security } \\
\text { challenges and strategies in e-learning }\end{array}$ & $\begin{array}{l}\text { Arabsorkhi \& } \\
\text { Yadegari }\end{array}$ & 2010 & $\begin{array}{l}\text { Standard security } \\
\text { requirement }\end{array}$ & $\begin{array}{l}\text { Managerial, technical and } \\
\text { procedural }\end{array}$ & $\begin{array}{l}\text { The custodian of } \\
\text { the delivery } \\
\text { service }\end{array}$ \\
\hline $\begin{array}{l}\text { Towards- secure learning applications: a } \\
\text { multi-agent plat form }\end{array}$ & $\begin{array}{l}\text { Carine \& } \\
\text { Webber }\end{array}$ & 2007 & $\begin{array}{l}\text { Technical security } \\
\text { requirement }\end{array}$ & - & $\begin{array}{l}\text { Technology and } \\
\text { application }\end{array}$ \\
\hline $\begin{array}{l}\text { E-learning and Information Security } \\
\text { Management }\end{array}$ & Hayaati & 2010 & $\begin{array}{l}\text { Public security } \\
\text { requirement }\end{array}$ & $\begin{array}{l}\text { It emphasizes on the } \\
\text { necessity of it }\end{array}$ & Delivery services \\
\hline $\begin{array}{l}\text { Understand the ethical implications of e- } \\
\text { learning security attacks by the students }\end{array}$ & Ramim \& Levy & 2010 & $\begin{array}{l}\text { Public security } \\
\text { requirement }\end{array}$ & $\begin{array}{l}\text { It emphasizes on the } \\
\text { necessity of it }\end{array}$ & $\begin{array}{l}\text { Services } \\
\text { recipients }\end{array}$ \\
\hline $\begin{array}{l}\text { approach of public Key Infrastructure to } \\
\text { expand the secure distributed environments of } \\
\text { e-learning and fluid learning advanced fluid }\end{array}$ & $\begin{array}{l}\text { Kambourakis, } \\
\text { Kontoni, } \\
\text { Rouskas \& } \\
\text { Gritzalis }\end{array}$ & 2007 & $\begin{array}{l}\text { Technical security } \\
\text { requirement }\end{array}$ & $\begin{array}{l}\text { The requirements based on } \\
\text { the confidence model. }\end{array}$ & $\begin{array}{l}\text { Infrastructure of } \\
\text { delivery services }\end{array}$ \\
\hline Privacy concerns in the field of e-learning & May \& Sébastien & 2011 & $\begin{array}{l}\text { Public security } \\
\text { requirement }\end{array}$ & $\begin{array}{l}\text { The requirements based on } \\
\text { privacy }\end{array}$ & $\begin{array}{l}\text { Services } \\
\text { recipients }\end{array}$ \\
\hline $\begin{array}{l}\text { Information security in the e-learning } \\
\text { platforms }\end{array}$ & Defta & 2011 & $\begin{array}{l}\text { Public and technical } \\
\text { security requirement }\end{array}$ & Procedural and technical & $\begin{array}{l}\text { Software of } \\
\text { delivery services }\end{array}$ \\
\hline $\begin{array}{l}\text { An engineering security methodology of web } \\
\text { for e-learning systems }\end{array}$ & Aljawarneh & 2011 & $\begin{array}{l}\text { Secure development } \\
\text { services issues }\end{array}$ & Technical & Delivery services \\
\hline
\end{tabular}

There are major points about the mentioned researches in Table 1. The first case is associated with more attitudes - not major- and techniques to secure issues in the field of e-learning. Another case is the lack of concurrent security of payment by various stakeholders in the field of e-learning. Final case is the lack of a comprehensive approach to manage issues and security requirements in the field of e-learning that some researchers focus on them in many new articles (Zuev, 2013; Hayaati, 2010).Considering these gaps, we focus on developing a systematic framework to secure e-learning issues. 


\section{Research methodology}

The qualitative studies have examined in the literature review of this research, which is connected to the subject of this investigation. However, there are not researches about providing a security framework in the field of e-learning. Consequently, we present a logical framework for the best formulating of previously researches by meta-synthesis method. Meta-synthesis is an assembly process of the results for the individual researches that are in the level of abstraction. However, some researches defined it as meta-evaluation or systematic study, which is wrong (Zimmer, 2006). The capabilities of this method lead to increase trends of using it as a useful scientific method for organizing and promoting qualitative research. Based on this issue, we try to utilize meta-synthesis method to formulate associated results of e-learning security fields and organize them as a logical framework, integration, interpretation and composition. Meta-synthesis method is associated with the implementation of different methods and Fig. 1 summarizes the method of this paper.

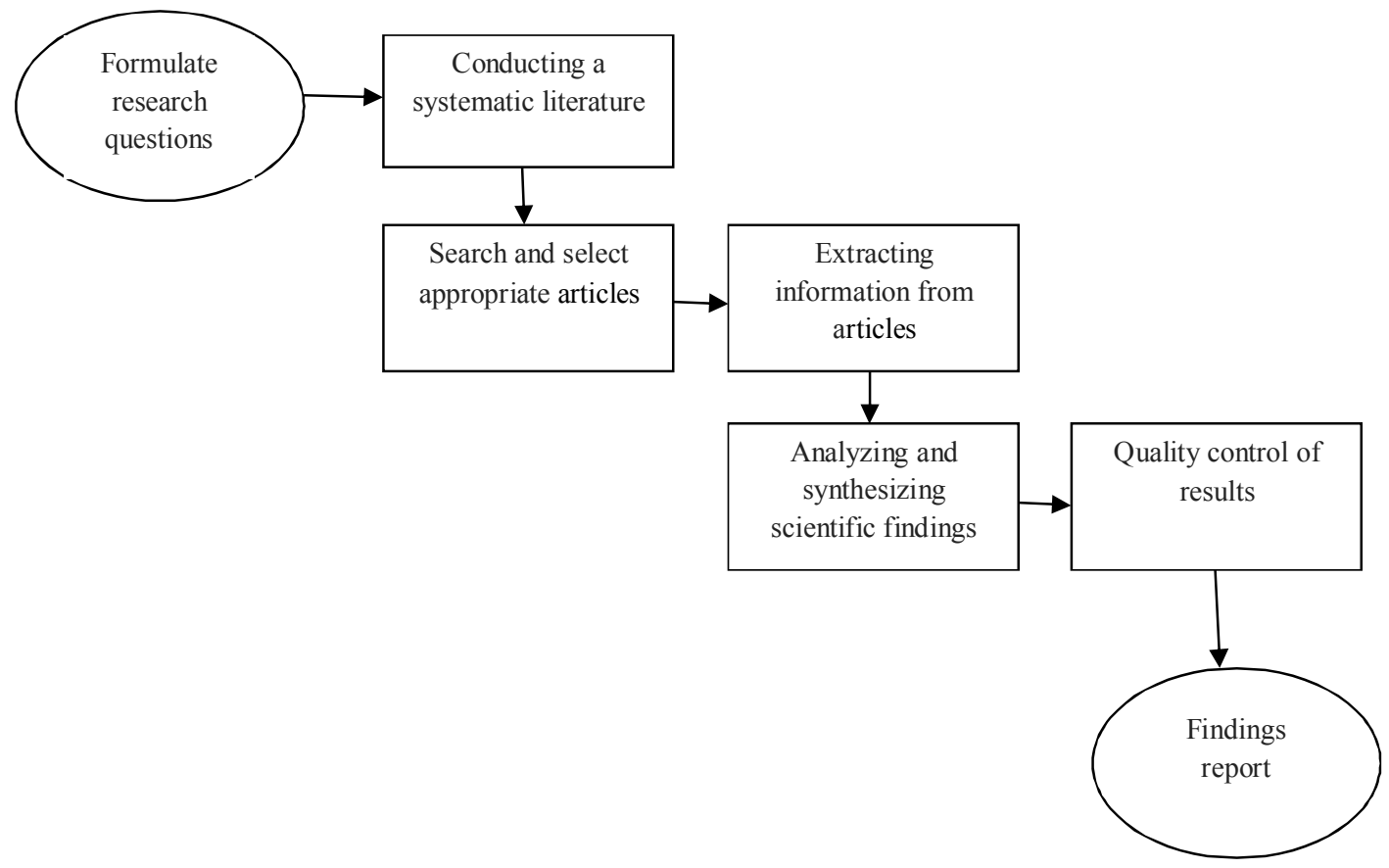

Fig. 1. Steps of meta-synthesis method

It should be noted that meta-synthesis method has utilized to build a framework to security issues in the field of e-learning.

\section{Findings research}

The research questions will discuss in the first part of this study. The following questions are associated to achieve desired goals using meta-synthesis method:

"Based on the security issues in the field of e-learning, what a logical framework is? And what its dimensions are?"

Previous studies are analyzed on the two features to formulate a logical framework to e-learning security requirements:

- Pure research in the field of e-learning security.

- Pure research in the field of e-learning.

We have aimed security issues in examining research in the field of e-learning that have formulated e-leaning. However, findings in the field of e-learning have identified key issues and elements, which 
have considered formulating e-learning services, directly. We suggest our framework to formulate elearning security issues at the end of this activity. In the following, we utilize different search engines to perform research, based on defined keywords. One or a set of groups and professional references have analyzed using variety search engines. In addition, academic centers have been recognized to select many articles and reliable references. Each of these databases has a number of professional scientific publications. We studied related articles to e-learning and e-learning security in the specification listed of these databases and their journals. In the next step, we evaluated and selected appropriate articles. A set of indications has been shown in the Table 2.

Table 2

Accepted and rejection criteria of articles

\begin{tabular}{|c|c|c|}
\hline index & Accepted criteria & Rejection criteria \\
\hline Geographical & All continents & - \\
\hline Language of research & English and Persian & other \\
\hline Time of study & $1980-2013$ & Before 1980 \\
\hline Methods & Qualitative & Quantitative \\
\hline Population of study & $\begin{array}{l}\text { E-learning, e-learning security, security } \\
\text { information }\end{array}$ & $\begin{array}{l}\text { Except e-learning, security e-learning, } \\
\text { security information }\end{array}$ \\
\hline Condition of study & $\begin{array}{l}\text { Aspects of e-learning security, functional } \\
\text { aspects, developing issues and components } \\
\text { of e-learning environments }\end{array}$ & $\begin{array}{l}\text { Except of Aspects of security e-learning, } \\
\text { functional aspects, developing } \\
\text { considerations and components of e-learning } \\
\text { environments }\end{array}$ \\
\hline Type of document & $\begin{array}{l}\text { Published articles in the journals and } \\
\text { international conferences }\end{array}$ & Personal opinions and personal websites \\
\hline
\end{tabular}

The process of selecting articles based on the meta-synthesis method is shown in Fig 2 and Fig. 3.

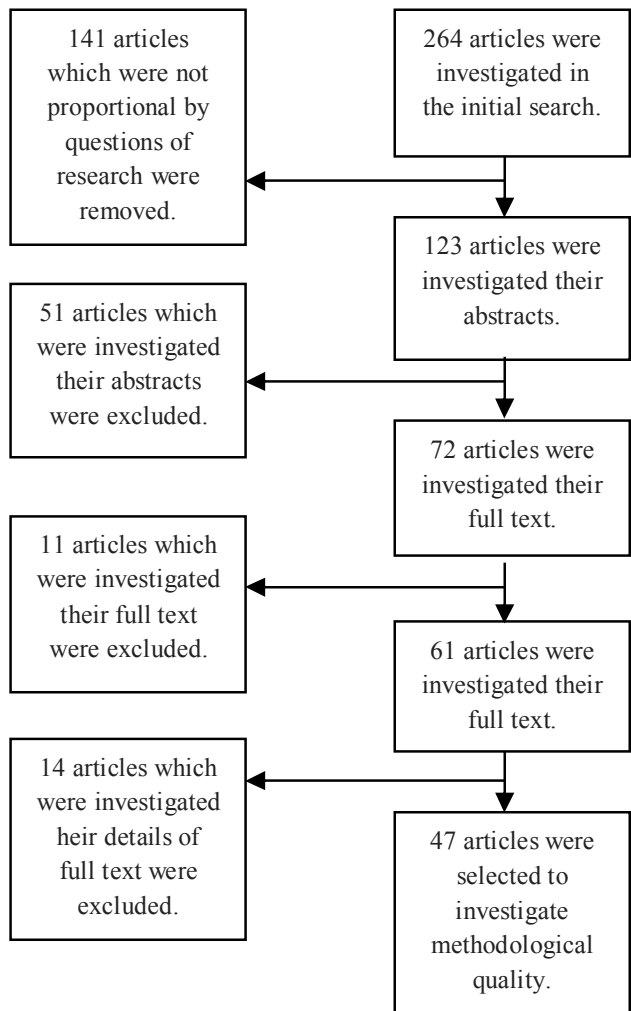

Fig. 3. Process of selecting appropriate articles in the field of e-learning

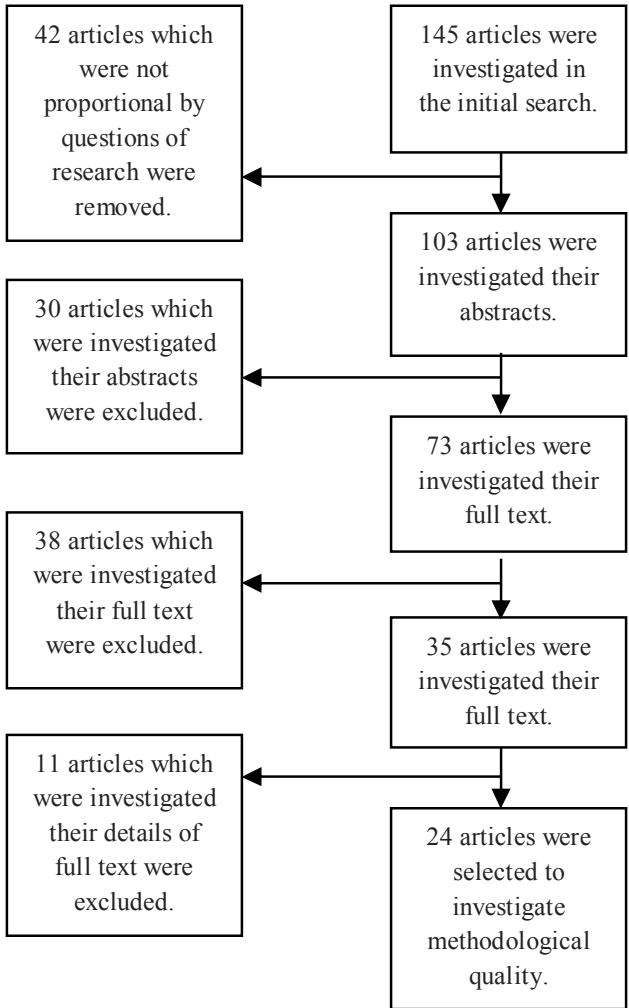

Fig. 2. Process of search and selection selecting of appropriate articles in the field of e-learning security 
There were 47 articles about e-learning security and 24 remaining articles about e-learning scope that have investigated CASP methods separately. Finally, 29 articles, which had e-learning security subjects and 17 articles, which had e-learning subjects obtained required scores to do a qualitative content analysis. We were studying selected articles to achieve related results of e-learning security concerns. Summary of obtained results are listed in the format of table. This table is used as input of analysis step and combining finding results of research. We have studied selected articles to achieve related results for security concerns of e-learning. Summary of obtained results are listed in the format of table. This table is used as input of analysis step and combining finding results of research. We searched topics, which have emerged among selected meta-synthesis studies, based on analysis of qualitative findings researches. In the other word, these topics are associated with major issues of elearning and e-learning security or they can be utilized to formulate the issues of this area. We identified issues by reviewing studies and findings shown in Fig. 4. Then, they organized in the same categories, which can describe issues of e-learning and e-learning security. This analysis is formulated as a separated table.

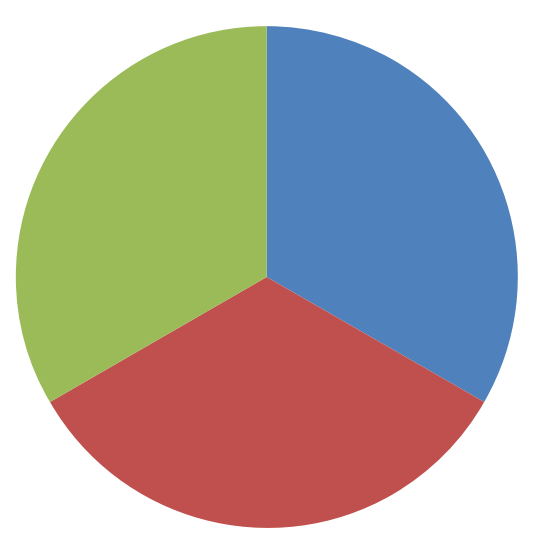

Customer oriented viewpoint $\quad$ Infrastructure oriented viewpoint $\quad$ Service oriented viewpoint

Fig. 4. The represented model to define security requirements of e-learning

Last issue of meta-synthesis method is a framework, which controls quality of findings. We used approaches to separate major studies in the qualitative research. However, we utilized a set of standard criteria in the process of meta-synthesis method as a CASP method to select qualified articles. Furthermore, we will apply both electronic and manual strategies to search all the relevant articles, comprehensively.

Accordingly, we provided a logical framework for security requirements of e-learning by metasynthesis method, analyzing frameworks, theoretical models in the field of e-learning and information security. The framework has identified purposes such as: designing, developing, managing, distributing and e-learning applications; identifying key references of e-learning security and nonsecurity; identifying key issues and e-learning decision variables in the mentioned fields; identifying domains of security or control objectives of e-learning in the mentioned fields. Consequently, we tried to obtain a three-dimensional model of e-learning and requirements of e-learning security. The three dimensions of this model are infrastructure-oriented viewpoint, service-oriented viewpoint and customer-oriented viewpoint. In each of mentioned approaches there are key issues as decision variables in this field. These topics are included indices, which are used for designing, developing and planning in that issue. We have enabled to define a conceptual framework, based on mentioned dimensions using meta-synthesis method. 
Table 4

The results of the data analysis of meta-synthesis

\begin{tabular}{|c|c|c|c|}
\hline & Category & Source ID & Metrics \\
\hline \multirow{15}{*}{ 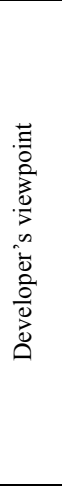 } & \multirow{5}{*}{ Technology } & \multirow{2}{*}{ e-learning aspects } & Designing software \\
\hline & & & Environment of development \\
\hline & & \multirow{3}{*}{ e-learning security aspects } & Secure development of software \\
\hline & & & Security requirement \\
\hline & & & Security patches \\
\hline & \multirow{5}{*}{ Plat form } & \multirow{2}{*}{ Consideration of e-learning } & Communication facilities \\
\hline & & & Multimedia features \\
\hline & & \multirow{3}{*}{ Consideration of security e-learning } & Security communications \\
\hline & & & Security Tools \\
\hline & & & Secure configuration \\
\hline & \multirow{5}{*}{ Support } & \multirow{2}{*}{ Consideration of e-learning } & Extensibility \\
\hline & & & Development Platform \\
\hline & & \multirow{3}{*}{ Consideration of security e-learning } & Security assurance \\
\hline & & & Security Evaluation \\
\hline & & & Security guidelines \\
\hline \multirow{19}{*}{ 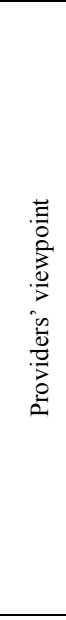 } & \multirow{5}{*}{$\begin{array}{l}\text { Applications and educational } \\
\text { services }\end{array}$} & \multirow{3}{*}{ Consideration of e-learning } & Remote learning \\
\hline & & & Learning by computers \\
\hline & & & Online education \\
\hline & & \multirow{2}{*}{ Consideration of security e-learning } & Security application \\
\hline & & & Security mechanisms \\
\hline & \multirow{5}{*}{ Media Services } & \multirow{2}{*}{ Consideration of e-learning } & Network \\
\hline & & & Portal \\
\hline & & \multirow{2}{*}{ Consideration of security e-learning } & Network security \\
\hline & & & Portal security \\
\hline & & \multirow{2}{*}{ Consideration of e-learning } & Distribution \\
\hline & \multirow{5}{*}{$\begin{array}{l}\text { Quality and quantity of } \\
\text { services }\end{array}$} & & Exchange /supply points \\
\hline & & \multirow{2}{*}{ Consideration of security e-learning } & Availability \\
\hline & & & Communication's Security \\
\hline & & \multirow{4}{*}{ Consideration of e-learning } & Content \\
\hline & & & Education \\
\hline & \multirow{4}{*}{$\begin{array}{l}\text { Components of } \\
\text { educational services }\end{array}$} & & Teachers \\
\hline & & & Financial \\
\hline & & \multirow{2}{*}{ Consideration of security e-learning } & Security services \\
\hline & & & Accuracy system performance \\
\hline \multirow{11}{*}{ 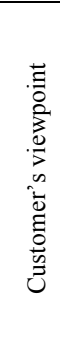 } & & & Course \\
\hline & & Consideration of e-learning & Education a leavens \\
\hline & Knowledge & consideration or e-learning & Assessment \\
\hline & Nnowieage & & Cooperation \\
\hline & & Consideration of security e-learning & Accuracy Content \\
\hline & & consideration or securty e-learming & Confidentiality \\
\hline & & Consideration of e-learning & Flexibility \\
\hline & & Constueration or e-teanting & Quality of Service \\
\hline & Customer's standards & & Accuracy of system performance \\
\hline & & Consideration of security e-learning & Availability \\
\hline & & & Reliability \\
\hline
\end{tabular}

\section{Conclusion}

We have presented a framework to formulate security concerns in the field of e-learning using metasynthesis method. This framework can be utilized as a support to security requirements engineering. This framework proceeds to security requirements engineering in the field of e-learning from several points. First, this logical framework is the best indicators for control objectives and security issues by introducing three viewpoints and diverse fields of e-learning with different security requirements. The requirements should be architected in security requirements engineering framework. Therefore, logical routine of requirements realizes in effect of using suggested framework. Secondly, each of these viewpoints and the scope of the definition have control objectives and specific security requirements. In addition, they are followed diverse security requirements based on the role of elearning fields. Hence, a key process or support function of security requirement engineering can play essential role for the logical framework. Ultimately, each of these areas has its security agencies that are players in the security requirements engineering. Obviously, there is a difference between each of areas of security requirement engineering and the roles of them in the diverse fields of security requirement engineering. Consequently, there is a rational practical screening by using logical 
framework. Accordingly, the proposed framework is examined to provide comprehensive support to security requirements in the field of e-learning.

\section{References}

Arabsorkhi, A., \& Yadegari, A., M. (2010).Identification and analysis of challenges and security strategies in elearning. Information Sciences and Technology, 26(2), 441-464.

Arabsorkhi, A., Yadegari, A., M., \& Kharat, M. (2009). Provide solutions and security requirements in e-learning. First International Conference on e-Learning.

Adams, A. \& Blandford, A. (2003). Security and Online Learning: To Protect or Prohibit, Idea Group Inc.

Al Bouna, B. \& Chbeir, R. (2006). Multimedia-based authorization and access control policy specification. Proceedings of the 3rd ACM workshop on secure web, 61-68.

Aljawarneh, S. (2011). A web engineering security methodology for e-learning systems. Network Security, 2011(3), 1215.

Anderson, J.K. (2009). The work-role transition of expert clinician to novice academic educator. Journal of Nursing Education, 48 (4), 203-208.

Assefa, S.\&Solms, V. (2009). An Information Security Reference Framework for e-Learning Management Systems (ISRFe-LMS). Proceedings of $9^{\text {th }}$ WCCE.

Balasundaram, S.R. (2011). Securing tests in E-learning environment. In Proceedings of the 2011 International Conference on Communication. Computing \& Security (ICCCS '11), 624-627.

Barlow, R. E. (2007). A study of security in learning management systems. Master's Essay.

Basha \& Dhavachelvan, (2010). Web Service Based Secure E-Learning Management System - Ewe MS. Journal of Convergence Information Technology, 5 (7).

Bleimann, U. (2004). Atlantis university: a new pedagogical approach beyond e-learning. Campus-wide Information Systems, 21(5), 191-195.

Cardenas, R.G. \& Sanchez, E.M. (2005). Security Challenges of Distributed e-Learning Systems. Fifth IEEE Int. Symp. And School on Advanced Distributed Systems (ISSADS), Springer, Berlin, 2005, no. 3563 in LNCS, pp. 538-544.

Webber, C. G., Lima, M. D. F. W., Casa, M. E., \& Ribeiro, A. M. (2007). Towards Secure e-Learning Applications: a Multiagent Platform. Journal of Software, 2(1), 60-69.

Chen, J.L. (2011). The effects of education compatibility and technological expectancy on e-learning acceptance. Computers \& Education, 57, 1501-1511.

Chin, K.L. \& Kon, P.N. (2003). Key factors for a fully online e-learning mode: A Delphi study. Proceedings of the 20th Annual Conference of the Australasian Society for Computers in Learning in Tertiary Education.

Chuang, U.H, Chen, C.U., Wu, T.C. \& Chao, H.C. (2012). Establish a Secure and Trustworthy ICT Environment for Educational Systems: A Case Study. Journal of Intelligent Manufacturing, 23(4), 965-975.

Defta L. (2011). Security Issues in E-learning Platforms. World Journal on Educational Technology, 3(3), 153-167.

Dong, Y., Li, M., Chen, M. \& Zheng, S. (2002). Research on intellectual property right problems of peer-to-peer networks. Electronic Library, 20(2), 143 - 150.

Eibl, C. J. (2008). Risk Analysis towards Secure E-Learning. LYICT 2008, Proc. on CD-ROM, ISBN 978-3-90188229-6.

Eibl, C. J. (2009). Privacy and Confidentiality in E-Learning Systems. Fourth International Conference on Internet and Web Applications and Services (ICIW 2009). IEEE Computer Society Press, ISBN 978-0-7695-3613-2.

El-Khatib, K., Korba, L., Xu, Y. \& Yee, G. (2003). Privacy and Security in E-Learning. Journal of Distance Education, 1(4), 1-19.

Furnell, S. M., \& Karweni, T. (2001). Security issues in online distance learning. VINE, 31(2), 28-35.

Furnell, S.M., \& Karweni, T. (2001). Security issues in online distance learning. VINE, 31(2), $28-35$.

Furnell, S.M., Onions, P.D., Knahl, M., Sanders, P.W., Bleimann, U., Gojny, U., \& Röder, H.F. (1998). A security framework for online distance learning and training. Internet Research, 8(3), 236-242.

Gelbord, B. (2003). On the use of PKI technologies for secure and private e-Iearning environments. 4th International Conference Conference on Computer Systems and Technologies: e-Learning, 568-572.

Alwi, N. H. M., \& Fan, I. S. (2010). E-learning and information security management. International Journal of Digital Society (IJDS), 1(2), 148-156.

Hamid, A. A. (2002).E-learning is it the "e" or the Learning that matters?. The Internet and Higher Education, 4, 311-316.

Hitchings, J. (1995). Deficiencies of the traditional approach to information security and the requirements for a new methodology. Proceedings of Computers \& Security, 14, 377-383.

Jalal, A., Zeb, M.A. \& Peshawar, P. (2008). Security enhancement for e-learning portal. International Journal of Computer Science and Network Security, 2(4), 236. 
Jethro, O. O., Grace, A. M., \& Thomas, A. K. (2012). E-Learning and its effects on teaching and learning in a global age. Indian Journal of Education and Information Management, 1(2), 73-78.

Kambourakis, G., Kontoni, D. P. N., Rouskas, A., \& Gritzalis, S. (2007). A PKI approach for deploying modern secure distributed e-learning and m-learning environments. Computers \& Education, 48(1), 1-16.

Kasse, P., \& Balunywa, W. (2013). An assessment of e-learning utilization by a section of Ugandan universities: challenges, success factors and way forward. Conference Papers - International Conference on ICT for Africa.

Khodabandeh, A., Afshari, H., \& Manian, A. (2010). Critical factors affecting e-learner's satisfaction an empirical study. Presented at World Conference on Educational Multimedia, Hypermedia and Telecommunications, Chesapeake, VA.

Lambrinoudakis, C., Gritzalis, S., Dridi, F., \& Pernul, G. (2003).Security requirements for e-government services: a methodological approach for developing a common PKI-based security policy. Computer Communications, 26, 1873-1883.

Lim, C.C. \& Jin, J.S. (2006). A study on applying software security to information systems: e-learning portals. IJCSNS, 6(3B), 162.

May, M., \& Sébastien, G. (2011). Privacy Concerns in E-learning: Is Using Tracking System a Thread?. International Journal of Information and Education Technology, 1(1), 1-8.

Mellado, D., Blanco, C., Sánchez, L. E. \& Fernández-Medina, E. (2010). A systematic review of security requirements engineering. Computer Standards \& Interfaces, 32(4), 153-165.

Moore, J.L., Dickson-Deane, C., \& Galyen, K. (2011). e-Learning, online learning, and distance learning environments: Are they the same?. The Internet and Higher Education, 14(2), 129-135.

Mutula, S. M. (2011). Ethics and trust in digital scholarship. Electronic Library, 29(2), 261-276.

Nickolova, M., \&Nickolov, E. (2007). Threat Model for User Security in E-Learning Systems. International Journal of Information Technologies and Knowledge, 341-347.

Noorman, M. \& Masrek, B. (2007). Measuring campus portal effectiveness and the contributing factors. CampusWide Information Systems, 24(5), 342-354.

Noorminshah, A.I. (2012).The impact of e-learning on students performance in tertiary institutions. International Journal of Computer Networks and Wireless Communications, 2 (2), 121-130.

Perakovic, D., \& Remenar, V. (2010). Security audit and mechanism of protecting e-Learning system at the Faculty of Transport and Traffic Sciences, Fakultetprometnihznanosti, Vukeliceva, 4, 10000.

Ramim, M. \& Levy, Y. (2006). Securing E-Learning Systems: A Case of Insider Cyber Attacks and Novice IT Management in a Small University. Journal of Cases on Information Technology, 8(4), 24-34.

Roffe, I. (2002). E-learning: engagement, enhancement and execution. Quality Assurance in Education, 10(1), 4050.

Smith, A.D. \& Rupp, W.T. (2004). Managerial implications of computer-based online/face-to-face business education: a case study. Online Information Review, 28(2), 100- 109.

Wong, D. (2007). A critical literature review on e-learning limitations. Journal for the Advancement of Science and Arts.

Weippl, E.R. (2005). In-depth tutorials: Security in e-learning. E-Learn Magazine, 3.

Wentling, T.L., Waight, C., Gallaher, J., La-Fleur, J., Wang, C., \& Kanfer, A. (2000). E-learning-A review of literature. University of Illinois.

Yau, J.C.K.,Hui, L.C.K.,Cheung, B., \&Yiu, S.M. (2003).eCX: a secure infrastructure for e-course delivery. Internet Research, 13(2), 116-125.

Yong, J. (2011). Security and privacy preservation for mobile e-learning via digital identity attributes. Journal of Universal Computer Science, 17 (2), 296-310.

Younis,A., Cater-Steel, A. \& Soar, J. (2013). IT infrastructure services as a requirement for e-learning system success. Computers \& Education, 69, 431-451.

Ziemba, E., \& Olszak, C.M. (2012). Building a regional structure of an information society on the basis of eadministration. Issues in Informing Science and Information Technology, 7, 129-150.

Zimmer, L. (2006). Qualitative meta-synthesis: A question of dialoguing with texts. Journal of Advanced Nursing, 53(3), 311-318.

Zisis, D., Lekkas, D. \&Spyrou, T. (2007).Security services in e-School and their role in the evaluation of educational processes. International Conference on Institutional Evaluation Techniques in Education, ICIETE07.

Zuev, V.I. (2012). E-learning Security Models. Management Information Systems, 7(2), 24-028. 